\title{
Balık Unu Yerine Kısmen Kullanılan Akasya (Acacia karroo) Tohumu Ununun Sazan (Cyprinus carpio) Yavrularında Büyüme ve Vücut Kompozisyonu Üzerine Etkisi*
}

\author{
Fatma Nida ÇOBAN, Mehmet ORUÇ, Hakan Murat BÜYÜKÇAPAR \\ KSÜ, Ziraat Fakültesi, Su Ürünleri Bölümü, Kahramanmaraş
}

Geliş (Received): 08.10.2015

Kabul (Accepted): 25.03.2016

\begin{abstract}
ÖZET: Akasya (Acacia karroo) tohumu ununun sazan (Cyprinus carpio) balıklarının pratik diyetlerinde protein kaynağı olarak kullanılabilirliğini belirlemek için laboratuvar koşullarında, 60 günlük besi denemesi yürütülmüştür. Akasya tohumu diyetlere $\% 5,10,15,20$ ve 25 oranlarında katılmıştır. Bu diyet grupları büyüme parametreleri bakımından balık unu ve soya unu ağırlıklı diyetle beslenen kontrol grubuyla karşılaştırılmıştır. Denemede canlı ağırlık kazanımı bakımından \%5, 10 ve 15'lik diyet grupları ile kontrol grupları arasında fark görülmezken $(\mathrm{P}>0.05), \% 20$ ve $25^{\prime}$ lik diyet gruplarında büyüme kontrol grubuna göre düşük bulunmuştur $(\mathrm{P}<0.05)$. Yüksek oranlarda (>\%15) akasya tohumu içeren diyetlerle beslenen balıklarda yağ oranı diğer gruplara göre düşük çıkmıştır $(\mathrm{P}<0.05)$. Akasya tohumunun sazan (Cyprinus carpio) balıklarının diyetlerine \%15'e kadar katılması balık büyümesi açısından herhangi bir sakınca yaratmamaktadır.
\end{abstract}

Anahtar Kelimeler: Sazan, Cyprinus carpio, akasya, Acacia karroo, vücut kompozisyonu, büyüme

\section{Effect of Partial Substitution of Fish Meal with Acacia (Acacia karroo) Seed Meal on Growth and Body Compositıon Profil of Carp (Cyprinus carpio) Fry}

ABSTRACT: A 60-day laboratory growth experiment was carried out to determine the potential nutritive value of acacia (Acacia karroo) seed meal as a dietary protein source of carp (Cyprinus carpio) fingerlings. Acacia seed meal was included in the diets at different levels $\% 5,10,15,20$ and 25. The growth parameters of fish feed these diets were compared to fish feed a fish meal and soybean meal based control diet. On the basis of the observed weight gain control, \%5, 10 and 15 diets were similar and significantly better than the other groups $(\% 20,25)(\mathrm{P}>0.05)$. Fish feed diets \%20, 25 showed significantly reduced growth performance compared to that with control diets. Fish feed diets containing higher levels (>\%15) acacia seed had significantly lower whole body fat content.

Acacia seed can be used up to $\% 15$ of diet as protein source in diets of carp without any adverse effects.

Key Words: Carp, Cyprinus carpio, Acacia, Acacia karroo, Body composition, growth

\section{GÍRIŞ}

Yetiştiricilikte mümkün olduğunca az masrafla maksimum yaşama ve büyüme oranını elde etmek hedeflenir. Yetiştiricilikteki üretim maliyetinin büyük bir kısmını yem oluşturmaktadır ve balıkların beslenmesi tahmini yapılmaktadır. Uygulanacak yanlış besleme teknikleri yem masrafinın artmasına, ekonomik olarak zarara ve çevre kirliliğine yol açabilmektedir (Korkut ve ark., 2007).

Balık unu balık yemlerinde hammadde olarak kullanılan son derece önemli bir protein kaynağıdır ve her geçen gün talep edilen miktarı artmaktadır, üretimi ise artan bu talebi karşılayamayacak duruma gelmiştir. $\mathrm{Bu}$ durum araştırmacıları karma yemler içersinde balık ununa alternatif olarak kullanılabilecek bitkisel ve hayvansal kökenli protein kaynakları ile ilgili çalışmalara yöneltmiştir (Yeşilayer ve ark., 2013). Bitkisel kökenli protein kaynaklarının ekim sahalarının daha geniş olması ve maliyet olarak daha avantajlı olmalarından dolayı balık rasyonları hazırlanırken balık unu yerine çeşitli oranlarda kullanımına yönelim daha fazla olmuştur. Bunun yanı sıra bitkisel protein kaynaklarının amino asit yapılarının yetersiz olması, proteinlerinin sindirim derecelerinin düşük olması, esansiyel yağ asitleri bakımından fakir olmaları gibi birtakım faktörler bu kaynakların kullanılabilmesini kısıtlamaktadır. $\mathrm{Bu}$ olumsuzlukları ortadan kaldırıp bitkisel protein kaynaklarının daha etkin kullanılabilmesi için çeşitli metotlardan yararlanılmaktadır. (Yeşilayer ve ark., 2013).

Araştırmamıza konu olan akasya (Acacia karroo) tohumunun Akdeniz bölgesinde bolca bulunabilen bir baklagil türü olup, balık unu yerine kısmen de olsa kullanılabileceği düşünülmektedir. Bu çalışma ile sazan (Cyprinus carpio) diyetlerinde akasya tohumunun alternatif protein kaynağı olarak kullanım olanaklarının araştırılması amaçlanmıştır. Çalışmayla sazan rasyonlarında büyümeyi engellemeden en uygun dozun saptanması amaçlanmıştır.

\section{MATERYAL ve METOT}

Balık ve Akvaryum Sistemi

Araştırmada kullanılan sazan yavruları Elazığ DSİ IX. Bölge Müdürlüğü'nden KSÜ Ziraat Fakültesi $\mathrm{Su}$ Ürünleri Bölümü'ne transfer edilmiștir. Yavrular metilen mavisiyle dezenfekte edilip $250 \mathrm{~cm}^{3}$ lük

\footnotetext{
*Bu araştırma KSÜ BAP tarafindan (Proje No: 2012/5-2 YLS) yüksek lisans çalışması olarak desteklenmiştir. Sorumlu yazar: Çoban, N., nidacoban@ksu.edu.tr
} 
fiberglas tanklarda $25{ }^{0} \mathrm{C}$ su sıcaklığında, yaklaşık olarak kuru maddede protein oranı $\% 35$, yağ oranı $\% 8$, kül oranı $\% 7$ ve enerji içeriği $19,96 \mathrm{MJ} / \mathrm{kg}$ olan yemle vücut ağırlıkları yaklaşık 13 g'a ulaşıncaya kadar beslenmişlerdir. Deneme başladığında bu yem deneme yemleriyle değiştirilmiştir. Deneme başlangıcından önce balıklar 80 lt'lik cam akvaryumlara tartılarak ve seçilerek 13'er adet ve iki tekerrürlü olarak yerleştirilmiştir. Toplam 12 adet akvaryum kullanılmıştır ve akvaryumlar metilen mavisiyle dezenfekte edilmiştir. Balıklar beş gün süreyle kontrol diyetiyle beslenip adaptasyonları sağlanmıştır. Deneme süresi 60 gün olup her 20 günde bir diyet gruplarındaki bütün balıkların ağırlık tartımı ve boy ölçümleri yapılmıştır. Tartım ve ölçüm yapılmadan bir gün önce balıklar aç bırakılmıştır. Balıklar deneme süresi boyunca günlük optimum yiyebilecekleri miktar olan ağırlıklarının \%3'ü oranında günün belirli saatlerinde 45 kez olmak üzere elle beslenmiştir. Deneme başlangıcında toplam on adet, deneme sonunda ise her akvaryumdan dört adet balık, vücut kompozisyonunun saptanması amacıyla saklanmıştır. Akvaryumlardaki su kalitesi iç ve dış filtreler ve elektronik isıtıcılarla kontrol altında tutulmuştur, yeterli oksijeni temin etmek için merkezi sistemli hava kompresörü kullanılmıştır ve ince plastik hava hortumlarıyla akvaryumlara eşit şekilde dağıtılmıştır. Deneme süresince su sicaklığı, sudaki çözünmüş oksijen miktarı ve $\mathrm{pH}$ günlük olarak ölçülmüş ve akvaryumlar haftalık olarak temizlenmiştir. Her sabah ölüm kontrolü yapılmıştır.

\section{Analitik Metotlar}

Akasya, balık unu, soya küspesi, mısır unu, deneme diyetleri ve balı örneklerinin kimyasal kompozisyonları AOAC (1990)'a göre yapılmıştır. Aminoasit kompozisyonu Türkiye Bilimsel ve Teknik Araştırma Kurumu, Marmara Araştırma Merkezi tarafından D.05.G106 yöntemi kullanılarak yapılmıştır (Çizelge 1). Yă̆ asidi kompozisyonu ise KSÜ Üniversite-Sanayi-Kamu İşbirliği Geliştirme, Uygulama ve Araştırma Merkezi tarafından GC-FID yöntemi kullanılarak yapılmıştır (Çizelge 2).

\section{Diyet Hazırlama ve Besleme}

Akasya tohumu gölgede kurutulduktan sonra değirmende çekilerek un haline getirilmiştir.

Denemede kullanılan rasyonların enerji ve protein oranları dengelenmiştir. Ayrıca diyetlerde sazanın esansiyel aminoasit ihtiyaçları Hossain ve ark., (2002)'nın bildirimi göz önünde tutularak dengelenmiştir.

Diyetleri oluşturan besin bileşenleri mikserde karıștırıldıktan sonra \%30 oranında su katılarak hamur haline getirilmiştir. Et makinesinin 2 no'lu eleğinden geçirilerek pelet haline getirilen diyetler $55{ }^{\circ} \mathrm{C}$ sıcaklıkta etüvde kurutulmuştur. Kontrol diyetinde ana protein kaynağı olarak \%40 oranında balık unu ve \%25 oranında soya küspesi kullanılmıştır (Çizelge 3).

Çizelge 1. Diyetlere katılan akasya tohumu unu, balık unu, mısır unu ve soya küspesi kuru maddedeki kimyasal kompozisyonu ve aminoasit içerikleri

\begin{tabular}{|c|c|c|c|c|}
\hline Besin bileşenleri (g/kg) & Akasya & Balık unu & Soya küspesi & Misir unu \\
\hline Ham Protein & 225,5 & 701,6 & 470,0 & 78,0 \\
\hline Ham Yă̆ & 40,55 & 21,3 & 17,5 & 16,21 \\
\hline Ham Selüloz & 81 & 5,0 & 60,0 & 26,0 \\
\hline Ham Kül & 29 & 135,0 & 60,0 & 55,2 \\
\hline Kuru Madde & 100 & 900,6 & 890,0 & 881,3 \\
\hline Toplam Enerji (MJ/kg) & 17,44 & 21,3 & 17,5 & 16,21 \\
\hline \multicolumn{5}{|c|}{ Esansiyel aminoasitler (g/kg) } \\
\hline Fenilalanin & 10,59 & 32,05 & 22,28 & 3,38 \\
\hline Histidin & 9,11 & 17,46 & 26,39 & 4,78 \\
\hline İzolöysin & 7,77 & 36,61 & 22,7 & 2,35 \\
\hline Löysin & 19,38 & 59,05 & 29,84 & 5,9 \\
\hline Metiyonin & 12,35 & 21,17 & 4,46 & 1,22 \\
\hline Treonin & 3,82 & 29,95 & 19,09 & 2,68 \\
\hline Lizin & 14,39 & 67,52 & 27,82 & 2,79 \\
\hline Valin & 8,08 & 39,70 & 24,05 & 3,17 \\
\hline \multicolumn{5}{|c|}{ Esansiyel olmayan aminoasitler (g/kg) } \\
\hline Alanin & 12,89 & 42,58 & 22,49 & 4,67 \\
\hline Aspartik asit & 15,68 & 100,81 & 57,82 & 9,79 \\
\hline Prolin & 10,58 & 31,57 & 24,69 & 4,06 \\
\hline Glutamik asit & 25,49 & 92,89 & 76,17 & 11,06 \\
\hline Serin & 12,02 & 25,9 & 25,71 & 3,52 \\
\hline Glisin & 13,87 & 33,59 & 19,68 & 2,81 \\
\hline
\end{tabular}

*Hesaplanmış değer; toplam enerji balık unu için $23.6 \mathrm{kj} / \mathrm{g}$, ham yağ için $39.5 \mathrm{kj} / \mathrm{g}$ ve karbonhidrat için ise $17.2 \mathrm{kj} / \mathrm{g}$ değerlerinden yararlanarak hesaplanmıştır (NRC,1993). 
Çizelge 2. Akasya tohumu yağ asit kompozisyonu (\%)

Butyric acid (C4:0)

0,128

Caproic acid (C6:0)

0,578

Caprylic acid (C8:0)

0,049

Capric acid (C10:0)

0,088

Lauric acid (C12:0)

0,115

Myristic acid (C14:0)

0,623

Palmitic acid (C16:0)

12,384

Palmiteolic acid (C16:1)

0,115

Heptadecanoic acid (C17:0)

0,063

Stearic acid (C18:0)

3,038

Oleic acid (C18:1)

32,101

Linoleik acid (C18:2)

44,480

Linolenic acid (C18:3)

1,629

Arachidic acid (C20:0)

0,386

Eicosenoic acid (C20:1)

0,238

Behenic acid (C22:0)

1,656

Eicosatrienoic acid (C20:0)

0,531

Eicosapentaenoic acid (C20:5)

0,467

Lignoseric acid (C24:0)

0,908

Nervonic acid (C24:1)

0,422 
Çizelge 3. Deneme diyetlerinin formülasyonu ve aminoasit kompozisyonu

\begin{tabular}{|c|c|c|c|c|c|c|}
\hline Diyet Bileşenleri (g/kg) & Kontrol & $\begin{array}{l}\text { Grup } 1 \\
(\% 5)\end{array}$ & $\begin{array}{l}\text { Grup } 2 \\
(\% 10)\end{array}$ & $\begin{array}{l}\text { Grup } 3 \\
(\% 15)\end{array}$ & $\begin{array}{l}\text { Grup } 4 \\
(\% 20)\end{array}$ & $\begin{array}{l}\text { Grup } 5 \\
(\% 25)\end{array}$ \\
\hline Balık Unu & 400 & 380 & 360 & 340 & 320 & 300 \\
\hline Soya Unu & 250 & 250 & 250 & 250 & 250 & 250 \\
\hline Misir Unu & 269 & 239 & 209 & 179 & 149 & 119 \\
\hline Akasya & 0 & 50 & 100 & 150 & 200 & 250 \\
\hline Ayçiçeği yağ1 & 70 & 70 & 70 & 70 & 70 & 70 \\
\hline DCP & 1 & 1 & 1 & 1 & 1 & 1 \\
\hline Vit-Min ${ }^{*}$ & 6 & 6 & 6 & 6 & 6 & 6 \\
\hline Mermer tozu & 1 & 1 & 1 & 1 & 1 & 1 \\
\hline Metiyonin & 1 & 1 & 1 & 1 & 1 & 1 \\
\hline Lizin & 1 & 1 & 1 & 1 & 1 & 1 \\
\hline Tuz & 1 & 1 & 1 & 1 & 1 & 1 \\
\hline Toplam & 1000 & 1000 & 1000 & 1000 & 1000 & 1000 \\
\hline \multicolumn{7}{|l|}{ Besin Bileșenleri (g/kg) } \\
\hline Ham Protein & 419 & 414 & 410 & 405 & 400 & 394 \\
\hline Ham Yağ & 127,2 & 125,6 & 124,1 & 122,6 & 121,7 & 119,53 \\
\hline Ham Selüloz & 22,91 & 26,20 & 29,49 & 32,78 & 36,07 & 39,36 \\
\hline Ham Kül & 67,0 & 66,9 & 68,2 & 66,3 & 67,4 & 68,9 \\
\hline Kuru Madde & 911,6 & 912,3 & 922,3 & 911,3 & 914,3 & 920,0 \\
\hline Toplam Enerji (MJ/kg) $)^{* *}$ & 19,96 & 19,93 & 19,98 & 19,85 & 19,82 & 19,78 \\
\hline \multicolumn{7}{|c|}{ Esansiyel Aminoasitler (g/kg) } \\
\hline Metiyonin & 9,89 & 10,05 & 10,21 & 10,34 & 10,50 & 10,65 \\
\hline Valin & 22,74 & 22,24 & 21,76 & 21,26 & 20,78 & 20,29 \\
\hline Löysin & 32,58 & 32,19 & 31,71 & 31,28 & 30,75 & 30,37 \\
\hline İsolöysin & 20,94 & 20,52 & 20,09 & 19,67 & 19,25 & 18,82 \\
\hline Fenilalanin & 19,29 & 19,06 & 18,84 & 19,46 & 19,52 & 19,58 \\
\hline Lizin & 34,78 & 34,06 & 33,26 & 32,54 & 31,83 & 31,12 \\
\hline Histidin & 14,85 & 14,81 & 14,76 & 14,72 & 14,68 & 14,63 \\
\hline Treonin & 17,47 & 16,98 & 16,49 & 15,99 & 15,50 & 15,01 \\
\hline \multicolumn{7}{|c|}{ Esansiyel Olmayan Aminoasitler (g/kg) } \\
\hline Alanin & 23,9 & 23,55 & 23,19 & 22,84 & 22,49 & 22,14 \\
\hline Aspartik Asit & 47,02 & 45,44 & 43,91 & 42,31 & 40,74 & 39,18 \\
\hline Prolin & 19,80 & 19,58 & 19,34 & 19,11 & 18,88 & 18,66 \\
\hline Glutamik Asit & 59,16 & 58,24 & 57,33 & 56,07 & 55,48 & 54,56 \\
\hline Serin & 17,72 & 17,70 & 17,67 & 17,65 & 17,62 & 17,60 \\
\hline Glisin & 19,10 & 19,04 & 18,97 & 18,91 & 18,75 & 18,77 \\
\hline
\end{tabular}

*Her 5kg'da bulunan vitamin mineral içerikleri 200.000.000 IU vitamin A, 200.000 IU vitamin D3, 200g vitamin E, $12 \mathrm{~g}$ vitamin $\mathrm{K}_{3}, 20 \mathrm{~g}$ vitamin B1, 0,03g vitamin B2, 200g niyasin, 50g capanthothenate, $20 \mathrm{~g}$ B6, 0,05g vitamin B12, $0,05 \mathrm{~g}$ vitamin B12, 0,5g D-biotin, $1,2 \mathrm{~g}$ folik asit, $200 \mathrm{~g}$ vitamin $\mathrm{C}$ ve $300 \mathrm{~g}$ inositol. $1200 \mathrm{~g}$ cholin chloride, $40 \mathrm{~g}$ mangan, $30 \mathrm{~g}$ çinko, $0,8 \mathrm{~g}$ bakır, $1 \mathrm{~g}$ iyodin, $0,15 \mathrm{~g}$ selenyum, $40 \mathrm{~g}$ magnezyum bulunmaktadır.

** Hesaplanmış değer; toplam enerji balık unu için $23.6 \mathrm{kj} / \mathrm{g}$, ham yağ için $39.5 \mathrm{kj} / \mathrm{g}$ ve karbonhidrat için ise 17.2 $\mathrm{kj} / \mathrm{g}$ değerlerinden yararlanarak hesaplanmıştır (NRC,1993).

İstatistiki Analiz

Denemeye ait araştırma verileri, "Varyans analizi" ve "Duncan çoklu karşılaştırma testi" nde, 0.05 önem düzeyine göre değerlendirilmiş olup söz konusu istatistiksel analizler SPSS paket programında yapılmıştır. 


\section{BULGULAR VE TARTISMA}

\section{Deneme Ortamı}

Deneme boyunca ölçülen oksijen $(\mathrm{mg} / \mathrm{lt})$, sıcaklık $\left({ }^{0} \mathrm{C}\right)$ ve $\mathrm{pH}$ değerleri $6.49 \pm 0.1-6.84 \pm 0.06$ oksijen $\mathrm{mg} / \mathrm{lt}, 24.16 \pm 0.40-24.97 \pm 0.17^{0} \mathrm{C}, 7.3 \pm 0.28-7.5 \pm 0.21$ $\mathrm{pH}$ arasında değişmiştir.

\section{Tartışma}

Deneme sonu itibariyle ortalama canlı ağırlık kazanımı 6.59 (Kontrol) ile $4.82 \quad(\% 20)$ arasında değişmiştir. Yapılan Duncan testine göre kontrol grubuyla \%5, 10, 15'lik gruplar arasında canlı ağırlık kazanımı farkı istatistiksel olarak önemsiz bulunmuştur $(\mathrm{P}>0.05)$, buna karşın $\% 20$ ve $25^{\prime}$ 'lik gruplarla kontrol grubu arasındaki fark istatistiki olarak önemli bulunmuştur $(\mathrm{P}<0.05)$. Başlangıç ağırlığ deneme sonu itibariyle yem alım miktarı, yem dönüşüm oranı, protein etkinlik oranı ve spesifik büyüme oranı ve istatistiksel olarak benzerlikleri ise çizelge 4'de, diyet gruplarının tüm vücut kompozisyonu analizi sonuçları ise çizelge 5' de verilmiştir.

Çizelge 4. Deneme sonu itibariyle canlı ağırlık kazanımı, spesifik büyüme, yem dönüşüm oranı, yem alım miktarları ve protein etkinlik oranları

\begin{tabular}{|c|c|c|c|c|c|c|}
\hline & Kontrol & $\% 5$ & $\% 10$ & $\% 15$ & $\% 20$ & $\% 25$ \\
\hline Baş. Ă̆. (g) & $13.53 \pm 0.3^{\mathrm{a}}$ & $13.78 \pm 0.4^{\mathrm{a}}$ & $13.72 \pm 0.3^{\mathrm{a}}$ & $13.60 \pm 0.4^{\mathrm{a}}$ & $13.60 \pm 0.4^{\mathrm{a}}$ & $13.54 \pm 0.3^{\mathrm{a}}$ \\
\hline Fin. ăg (g) & $33.32 \pm 1.6^{\mathrm{a}}$ & $31.89 \pm 1.5^{\mathrm{ba}}$ & $30.07 \pm 1.4^{\mathrm{cb}}$ & $29.71 \pm 1.2^{\mathrm{cb}}$ & $28.08 \pm 1.6^{\mathrm{c}}$ & $28.22 \pm 1.4^{\mathrm{c}}$ \\
\hline Ăg. Kaz. (g) & $6,59 \pm 0,6^{\mathrm{a}}$ & $6,03 \pm 0,3^{\text {ba }}$ & $5,44 \pm 0,5^{\text {ba }}$ & $5,36 \pm 0,2^{\mathrm{ba}}$ & $4,82 \pm 0,3^{b}$ & $4,96 \pm 0,1^{\mathrm{b}}$ \\
\hline Yem alımı & $11.60 \pm 0.9^{\mathrm{a}}$ & $11.65 \pm 0.8^{\mathrm{a}}$ & $11.81 \pm 0.9^{\mathrm{a}}$ & $11.69 \pm 0.8^{\mathrm{a}}$ & $11.26 \pm 0.7^{\mathrm{a}}$ & $10.97 \pm 0.7^{\mathrm{a}}$ \\
\hline YDO & $1,77 \pm 0.1^{\mathrm{a}}$ & $1.92 \pm 0.1^{\mathrm{a}}$ & $2.38 \pm 0.4^{\mathrm{a}}$ & $2.27 \pm 0.3^{\mathrm{ab}}$ & $2.44 \pm 0.3^{\mathrm{b}}$ & $2.20 \pm 0.1^{\mathrm{b}}$ \\
\hline PER & $1.39 \pm 0.1^{\mathrm{a}}$ & $1.30 \pm 0.1^{\mathrm{a}}$ & $1.23 \pm 0.2^{\mathrm{a}}$ & $1.24 \pm 0.2^{\mathrm{a}}$ & $1.15 \pm 0.1^{\mathrm{ab}}$ & $1.18 \pm 0.08^{\mathrm{b}}$ \\
\hline SBO & $1.50 \pm 1.1^{\mathrm{a}}$ & $1.39 \pm 0.1^{\mathrm{a}}$ & $1.30 \pm 0.1^{\mathrm{a}}$ & $1.30 \pm 0.1^{\mathrm{ab}}$ & $1.20 \pm 0.1^{\mathrm{b}}$ & $1.23 \pm 0.08^{\mathrm{b}}$ \\
\hline
\end{tabular}

Aynı harfle gösterilen ortalamalar istatistiki olarak benzerdir $(\mathrm{P}>0.05)$.

Çizelge 5. Diyet gruplarının tüm vücut kompozisyonu analizi sonuçları (\%)

\begin{tabular}{lllll}
\hline \multirow{2}{*}{$\begin{array}{l}\text { Giyet } \\
\text { Grupları }\end{array}$} & \multicolumn{4}{c}{ Kalık eti kompozisyonu (yaş) (\%) } \\
\hline Başlangıç & $22,37 \pm 0,33$ & Kül & Protein & Yă̆ \\
Kontrol & $25,18 \pm 0,31^{\mathrm{dc}}$ & $1,75 \pm 0,08$ & $14,70 \pm 0,25$ & $6,82 \pm 0,50$ \\
$\mathbf{5 \%}$ & $26,83 \pm 0,14^{\mathrm{b}}$ & $1,73 \pm 0,11^{\mathrm{ba}}$ & $14,87 \pm 0,56^{\mathrm{a}}$ & $9,36 \pm 0,11^{\mathrm{a}}$ \\
$\mathbf{1 0 \%}$ & $24,92 \pm 0,43^{\mathrm{d}}$ & $1,98 \pm 0,02^{\mathrm{a}}$ & $15,78 \pm 0,20^{\mathrm{a}}$ & $9,94 \pm 0,78^{\mathrm{a}}$ \\
$\mathbf{1 5 \%}$ & $24,05 \pm 0,09^{\mathrm{e}}$ & $1,74 \pm 0,09^{\mathrm{ba}}$ & $15,60 \pm 0,11^{\mathrm{a}}$ & $9,31 \pm 0,81^{\mathrm{a}}$ \\
$\mathbf{2 0 \%}$ & $28,86 \pm 0,14^{\mathrm{a}}$ & $1,67 \pm 0,17^{\mathrm{b}}$ & $15,66 \pm 0,09^{\mathrm{a}}$ & $8,65 \pm 0,49^{\mathrm{ba}}$ \\
$\mathbf{2 5 \%}$ & $25,90 \pm 0,24^{\mathrm{c}}$ & $1,37 \pm 0,02^{\mathrm{c}}$ & $14,73 \pm 0,19^{\mathrm{a}}$ & $6,61 \pm 1,04^{\mathrm{b}}$ \\
\hline Ayn & $1,29 \pm 0,06^{\mathrm{c}}$ & $15,14 \pm 0,22^{\mathrm{a}}$ & $6,80 \pm 0,69^{\mathrm{b}}$ \\
\hline
\end{tabular}

Aynı harfle gösterilen ortalamalar istatistiki olarak benzerdir $(\mathrm{P}>0.05)$.

Akasyanın kültürü olmadığı için yem maliyeti etkisi tartışılamamıştır. Akasyanın doğal ortamda toplatılması ve tohumunun çıkarılması maliyetli olarak gözükebilir fakat bu, maliyet hesabını tam olarak yansitmayabilir.

Sazan balıklarının rasyonlarına balık unu yerine $\% 15$ 'den fazla akasya tohumu (Acacia karroo) katılması büyüme parametrelerini olumsuz yönde etkilemiştir. $\mathrm{Bu}$ olumsuzluğun sebebinin proteinin etkin bir şekilde kullanılamaması olabileceği gibi rasyonlarda herhangi bir amino asit eksikliğinin olabileceği veya rasyonların birtakım antibesinsel faktörleri içeriyor olabileceği düşünülmektedir. Bu sonuç Hossain ve ark. (2001)'nın bulmuş olduğu sonuçla da uyum içersindedir. Araştırmacılar yapmış oldukları bu çalışmada aynalı sazan diyetlerinde \%12'den fazla Sesbania aculeata kullanımının içersindeki tanen ve saponin gibi çeşitli antibesinsel faktörlerin varlığından dolayı büyüme parametrelerini olumsuz etkilediğini ortaya koymuşlardır. Balıklar normal bir büyüme ve metabolizma için on esansiyel aminoasite (arjinin, histidin, fenilalanin, lizin, metiyonin, treonin, triptofan, löysin, izolöysin, valin) ihtiyaç duymaktadırlar (Wilson, 1986). Bu aminoasitler bazı araştırıcılar tarafından belirli balık türleri için çalışılmıştır (Ketola, 1982; Santiago ve Lovell, 1988; NRC, 1993; Cowey, 1994). $\mathrm{Bu}$ esansiyel aminoasitlerin eksikliği rasyondaki proteinin tam olarak kullanılamaması ve dolayısıyla büyümenin gerilemesi gibi olumsuzluklara yol açmaktadır. Protein sentezi rasyonda bulunan en düşük düzeydeki aminoasit seviyesinde gerçekleştiğinden herhangi bir aminoasitin eksikliği durumunda diğer aminoasitler normal değerlerinde olsa bile balıkların gelişmesi açısından olumsuzluklara neden olmaya yeterlidir (Doğan ve Erdem, 2008). (Akness ve ark., 2008)'nın bildirdiğine göre ise balık besleme çalışmalarında kullanılan bitkisel protein kaynaklarının 
aminoasit içerikleri incelendiğinde hayvansal protein kaynaklarına göre daha fakir olduğu görülmüştür. Aynı eksikliğin çalışmamızda kullanılan akasya tohumu için de geçerli olabileceği düşünülüp bu açığı kapatmak için rasyonlar hazırlanırken sazan balıklarının ihtiyaç duyduğu esansiyel aminoasit gereksinimi (Hossain ve ark., 2002) göz önünde bulundurularak rasyonlar esansiyel aminoasit bakımından yeterli seviyeye getirilmiştir. Gökkuşağı alabalıkları üzerinde yapılan bir çalışma sonucunda soya küspesinin içerdiği proteaz inhibitörlerinin bu balıklarda protein sindirilebilirliğini düşürdüğü ve gerilemeye neden olduğu belirlenmiştir (Krogdahl ve ark., 1994). Sazan (Cyprinus carpio) balıkları için ise uygulanan tanenin \%2'den fazla olması yem alımını olumsuz etkilemiştir (Becker ve Makkar, 1999). Tüm bu olumsuzlukların giderilmesi için rasyonda kullanılan hammaddelerin birtakım işlemlerden geçirilmesi veya rasyona enzim ilavesi gibi çözümler üzerinde çalışılmaktadır. Buradan elde edilecek başarılı sonuçlar kültür balıkçılığının gelişmesi açısından önemlidir (Erdoğan, 2008). Buna paralel olarak Büyükçapar ve Kamalak (2010) aynalı sazan (Cyprinus carpio) yavrularının diyetlerinde yabani bezelyenin (Pisum elatius) ham olarak \%10'a kadar kullanılabileceğini, 1sıtıldığ olanağının \%30'a kadar çıktığını bildirmişlerdir. Yapılan başka bir çalışmada ise aynalı sazan (Cyprinus carpio) diyetlerine $121{ }^{\circ} \mathrm{C}$ sicaklıkta $10-30 \mathrm{dk}$ isitılarak $\% 40$ oranında katılan Culban'1n (Vicia peregrina) balığın büyüme performansina olumsuz etkisinin olmadığı belirtilmiştir (Büyükçapar, 2012). Bu bilgiler doğrultusunda yapılan bu araştırmada rasyonda kullanılan alternatif protein kaynağının bitkisel kökenli olmasından dolayı içersinde birtakım antibesinsel faktörler içerebileceğinden, diyet grupları arasındaki farklılıkların bu faktörlerin varlığından kaynaklanıp kaynaklanmadığını belirlemek için bundan sonraki yapılacak çalışmalarda bu antibesinsel faktörlerin varlığ incelenerek değerlendirilmesinin daha uygun olacağ1 düşünülmektedir.

\section{SONUÇ}

$\mathrm{Bu}$ araştırmada kullanılan akasya (Acacia karroo) bölgedeki park, bahçe ve arazilerde bol miktarda bulunmaktadır. Ancak kültürü yapılmamaktadır, bu da maliyet hesabının yapılmasını kısıtlayabilmektedir.

Rasyona \% 15'den fazla akasya tohumu katılması sazan balıklarında büyüme parametrelerini olumsuz etkilemiştir. $\mathrm{Bu}$ olumsuzluk esansiyel aminoasit miktarlarının balık ununa göre daha az olmasından kaynaklanabileceği gibi baklagil tohumlarında bulunan antibesinsel faktörlerden de olabilir. Bu olumsuzlukların giderilmesi için antibesinsel faktörlerin eșik limitleri, balıkların fizyolojik ve ekolojik özellikleri üzerine etkileri ve farklı antibesinsel faktörlerin birbirleri arasındaki etkileşimin nasıl sonuçlandığını ortaya koyan daha ayrıntılı araştırmalara ihtiyaç duyulmaktadır.

\section{KAYNAKLAR}

Aksnes, A., Mundheim, H., Toppe, J., Albrektsen, S., 2008. The Effect of Dietary Hydroxypoline Supplementation on Salmon (Salmo salar L.) Fed High Plant Protein Diets. Aquaculture, 275(1-4): 242-249.

AOAC, 1990. Oficial Methods of Analysis (15th ed.) Association of Official Analytical Chemists, Washington DC, USA. s. 69-88.

Becker, K., Makkar, H.P.S., 1999. Effects of Dietary Tannic Acid and Quebracho Tannin on Growth Performance and Metabolic Rates of Common Carp (Cyprinus carpio L.). Aquaculture, 175:327-335.

Büyükçapar, H.M., 2012. Growth Performance and Body Composition in Mirror Carp (Cyprinus carpio) Fed Culban Seed (Vicia peregrina) With Different Heat Treatments. Kafkas Üniversitesi Veteriner Fakültesi Dergisi, 18(3):389-394.

Büyükçapar, H.M., Kamalak, A., 2010. Nutritive Value of Wild Pea (Pisum elatius) Seed as a Dietary Protein Source for Fingerlings of Mirror Carp (Cyprinus carpio). The Israeli Journal of Aquaculture, 62(4):272-280.

Cowey, C.B., 1994. Amino Acid Requirements of Fish: A Critical Appraisal of Present Values. Aquaculture, 124:1-11.

Doğan, G., Erdem, M., 2008. Balıklarda protein metabolizmas1. Journal of Fisheries Sciences. 2 (1): 30-40.

Emre, Y., Sevgili, H., Sanli, M., 2008. Partial Replacement of Fishmeal with Hazelnut Meal in Diets for Juvenil Gilthead Sea Bream (Sparus aurata). The Israeli Journal of Aquaculture, 60(3):198-204.

Erdoğan, F., 2008. Alabalık yemlerinde alternatif protein kaynakları kullanımı ve kültür balıkçılığının geleceği açısından önemi. Süleyman Demirel Üniversitesi Eğirdir Su Ürünleri Fakültesi Dergisi, 4(1-2):74-85.

Hossain M.A., Focken U., Becker K., 2001. Evaluation of an Unconventional Legume Seed, Sesbania aculeata, as a Dietary Protein Source for Common Carp (Cyprinus carpio). Aquaculture, 198:129-140.

Hossain, M.A., Focken, U., Becker, K., 2002. Nutritional Evaluation of Dhannincha (Sesbania aculeata) Seeds as a Dietary Protein Source for Tilapia (Oreochromis niloticus). Aquaculture Research, 33(9):653-662.

Ketola, H.G., 1982. Amino Acid Nutrition of Fishes: Requirements and Supplementation of Diets. Comparative Biochemistry and Physiology Part B: Comparative Biochemistry. 73(1): 17-24.

Korkut, A.Y., Kop, A., Demirtaş, N., Cihaner, A., 2007. Balık beslemede gelişim performansının izleme yöntemleri. Ege Üniversitesi Su ürünleri Dergisi, 24 (1-2): 201-205. 
Krogdahl, A., Lea, T.B., Olli, J.J., 1994. Soybean Proteinase Inhibitors Affect Intestinal Trypsin Activities and Amino Acid Digestibilities in Rainbow Trout (Oncorhynchus mykiss). Comparative Biochemistry and Physiology, 107A, 215-219.

NRC, 1993. Nutrient Requirement of fish. National Academy Press, Washington DC. s. 114.

Pereira, T.G., Oliva-Teles, A., 2002. Preliminary Evaluation of Pea Seed Meal in Diets for Gilthead Sea Bream (Sparus aurata) Juveniles. Aquaculture Research, 33, 1183-1189.

Santiago, C.B., Lovell, R.T., 1988. Amino Acid Requirements for Growth of Nile Tilapia. J. Nutr. 112, (12), 1540-6.
Wilson, R.P., Halver, J.E., 1986. Protein and Amino Acid Requirements of Fishes. Annual Review of Nutrition, 6:225-244.

Yeşilayer, N., Kaymak, İ.E., Gören, H.M., Karslı, Z., 2013. Balık yemlerinde balık ununa alternatif bitkisel protein kaynaklarının kullanım olanakları. Gaziosmanpaşa Bilimsel Araştırma Dergisi, 4, 1230.

Yiğit, N.Ö., Dulluç, A., Koca, S.B., Didinen, B.I., 2013. Aynalı sazan (Cyprinus carpio, L. 1758) yemlerinde soya küspesi yerine kanola küspesi kullanımının büyüme ve vücut kompozisyonu üzerine etkisi. Tarım Bilimleri Dergisi, 19:140-147. 